\title{
Investigation of Heavy Concretes Produced with Heavy Artificial Aggregates
}

\author{
Ş. KILINÇARSLAN* \\ SDÜ, Engineering Fac., Civil Engineering Department, Isparta, Turkey
}

\begin{abstract}
For the adequate shielding of the radiological equipment using $\mathrm{X}$ and gamma rays, special materials with high attenuation properties are needed. This objective may be achieved by the use of concrete. Concrete engineers and technologists must take the role of aggregates more seriously, since there are increasing demands of modern concrete mixtures in terms of technological properties and greater economy. Heavyweight concrete contains aggregates that are natural or synthetic. In this study, metal industry waste products such as iron filings and rebar pieces were used to produce heavy concrete. Physical, mechanical and radiation shielding properties of the obtained concrete with barite, aggregates and artificial aggregates were studied. According to test results, the concrete produced with artificial aggregates can provide the desired physical properties. Radiation shielding coefficient was found to be proportional to the density of concrete.
\end{abstract}

DOI: 10.12693/APhysPolA.128.B-469

PACS: 28.41.Qb, 61.43.Gt

\section{Introduction}

Heavy weight concrete is most commonly used for radiation shielding, counterweights and other applications where a high mass-to-volume ratio is desired [1]. The most important factor that distinguishes the conventional concretes from heavy concrete, is the use of various heavy aggregates during production [2-3]. The special aggregates which are usually utilized in the production of heavy concrete are natural aggregates such as barite, magnetite, limonite and artificial aggregates such as industrial residues like iron and lead particles [4]. Research of artificial heavy aggregates for production of heavy concrete is very important in terms of both, the environmental protection and economical recovery and reuse of recycled materials [5-7].

With the increase of the density also increases the radiation protection capability of the concretes [8-10]. In this study, in order to obtain heavy concrete, the waste products of metal industry, such as iron filings and rebar pieces, were used. The amounts of waste metals used as aggregates were such, as to obtain the same density of the concrete as the density of heavy concrete, produced using barite aggregates. Heavy concrete produced using both the barite and the waste metal, were tested and physical and mechanical parameters of the concrete were obtained.

\section{Materials and method}

Three different series of concrete, were prepared to test the contribution of the content of barite, normal aggregate and artificial aggregate in the concrete to protection against $\gamma$-rays. Each concrete was prepared using a constant ratio of water and cement. The concrete with

*e-mail: semsettinkilincarslan@sdu.edu.tr normal aggregate is denoted as $\mathrm{OC}$, concrete with barite is denoted as BC and concrete with artificial aggregate is denoted as AC.

The values of mixture ratio for all types of concretes are given in Table I. In this study, the CEM $142.5 \mathrm{R}$ type of cement was used. Barite aggregate was obtained from Şarkikarağaç-Isparta region in south of Sultandağları barite region, where the purity of barite ore is $90 \%$ of $\mathrm{BaSO}_{4}$. The ordinary aggregate was from the aggregate mine located in Isparta. As artificial aggregate, the rebar pieces and iron filings were used. All samples were cast in a standard mould of cubic shape with a dimension of $15 \mathrm{~cm}$. The concrete samples were cast in three steps by vibrating the mould at each step on shaking tables to ensure the compaction. The samples were then kept for 24 hours at $20 \pm 2^{\circ} \mathrm{C}$ in a curing room having $95 \pm 5 \%$ of relative humidity. Later, they were preserved for 27 days in lime saturated water prior the beginning of experiments. Mix proportions and some fresh properties of the concretes are given in Table I.

Workability of fresh concrete and the 28-day air-dry density were measured for all sample batches. Compressive strengths were measured using an automatic compression testing machine with a maximum capacity of $1000 \mathrm{kN}$. For all tests, each value was taken as the average of three samples. Compressive strength tests were performed at 7, 28, and 90 days after casting. Flexural strength test were performed at 28 days after casting. This test was performed on prismatic specimens with dimensions of $100 \times 100 \times 500 \mathrm{~mm}^{3}$. Using the four point loading procedure of ASTM C 78. The linear attenuation coefficients were determined by measuring the transmission of $\gamma$-rays through targets of two different thicknesses $(2.4 \mathrm{~cm}$ and $4.8 \mathrm{~cm})$. The $\gamma$-rays were obtained from ${ }^{60} \mathrm{Co}$ sources which emit photons with energy of $1.173 \mathrm{MeV}$. The linear attenuation coefficient was obtained using the Lambert law. 
Mixture proportions for a cubic meter of concrete and some fresh properties.

\begin{tabular}{|c|c|c|c|c|c|c|c|c|c|c|c|}
\hline \multirow[b]{2}{*}{ Concrete } & \multirow[b]{2}{*}{ Cement } & \multirow[b]{2}{*}{ Water } & \multirow[b]{2}{*}{ SP } & \multicolumn{2}{|c|}{ Aggergate } & \multicolumn{2}{|c|}{ Barite } & \multicolumn{2}{|c|}{ Artificial } & \multirow[b]{2}{*}{$\begin{array}{c}\text { Slump } \\
\text { [mm] }\end{array}$} & \multirow{2}{*}{$\begin{array}{c}\text { Fresh } \\
\text { density } \\
{\left[\mathrm{kg} / \mathrm{m}^{3}\right]}\end{array}$} \\
\hline & & & & Fine & Coarse & Fine & Coarse & $\begin{array}{l}\text { Iron } \\
\text { filings }\end{array}$ & $\begin{array}{l}\text { Rebar } \\
\text { pieces }\end{array}$ & & \\
\hline $\mathrm{OC}$ & \multirow{3}{*}{185} & \multirow{3}{*}{360} & \multirow{3}{*}{5} & 703 & 1105 & & & & & 72 & 2443 \\
\hline $\mathrm{BC}$ & & & & & & 1113 & 1705 & & & 69 & 3450 \\
\hline $\mathrm{AC}$ & & & & 506 & 813 & & & 510 & 852 & 65 & 3276 \\
\hline
\end{tabular}

\section{Results}

Some of the physical and mechanical properties of the hardened concretes are given in Table II. Highest density was obtained in BC, while lowest water absorption capacity was obtained in $\mathrm{AC}$. The values of compressive strengths of $\mathrm{OC}$ and $\mathrm{BC}$ were found to be close to each other. The compressive strengths of $\mathrm{AC}$ concrete were found to be higher than those of ordinary concrete (NC) by $10 \%$ after 28 days and by $7 \%$ after 90 days. The flexural strengths of $\mathrm{AC}$ concrete were found to be higher than those of ordinary concrete (OC) by 35\%. Rebars and iron powders have increased the flexural strength.

TABLE II

Some of the physical and mechanical properties of the hardened concretes.

\begin{tabular}{|c|c|c|c|c|c|c|}
\hline \multirow[t]{2}{*}{ Concrete } & \multirow[t]{2}{*}{$\begin{array}{l}\text { Density } \\
{\left[\mathrm{kg} / \mathrm{m}^{3}\right]}\end{array}$} & \multirow{2}{*}{$\begin{array}{c}\text { Water } \\
\text { absorption } \\
\text { capacity [\%] }\end{array}$} & \multicolumn{3}{|c|}{$\begin{array}{c}\text { Compressive } \\
\text { strength }\left(f_{c}\right) \\
{[\mathrm{MPa}]}\end{array}$} & \multirow{2}{*}{$\begin{array}{c}\text { Flexural } \\
\text { strength } \\
{[\mathrm{MPa}]}\end{array}$} \\
\hline & & & $\begin{array}{c}7 \\
\text { days }\end{array}$ & $\begin{array}{c}28 \\
\text { days }\end{array}$ & $\begin{array}{c}90 \\
\text { days }\end{array}$ & \\
\hline $\mathrm{OC}$ & 2403 & 4.38 & 33.5 & 45.8 & 53.1 & 4.21 \\
\hline $\mathrm{BC}$ & 3405 & 2.35 & 36.2 & 47.3 & 55.6 & 4.34 \\
\hline $\mathrm{AC}$ & 3240 & 2.21 & 37.3 & 50.2 & 56.7 & 6.45 \\
\hline
\end{tabular}

The linear attenuation coefficients $\mu$ for three different concretes have been measured at photon energy of $1.173 \mathrm{MeV}$. The measured results are shown in Table III.

TABLE III

The calculated values of attenuation coefficients $\mu$ at $1.173 \mathrm{MeV}$

\begin{tabular}{c|c|c|c}
\hline \hline Concrete & $\begin{array}{c}\text { Density }(\rho) \\
{\left[\mathrm{kg} / \mathrm{dm}^{3}\right]}\end{array}$ & $\begin{array}{c}\text { Linear attenuation } \\
\text { coefficient }(\mu)\end{array}$ & $\mu / \rho$ \\
\hline OC & 2.403 & 0.1469 & 0.06113 \\
BC & 3.405 & 0.2085 & 0.06123 \\
$\mathrm{AC}$ & 3.241 & 0.1981 & 0.06114
\end{tabular}

As can be seen from Table III, the linear attenuation coefficient $\mu$ increases with the increasing density of material, and the mass attenuation coefficients $\mu / \rho$ is constant, as it is expected.

The obtained results show the effect of artificial aggregate on the mechanical properties and linear attenuation coefficient $\mu$. Thus, the concretes loaded with the rebar pieces and iron filings would be preferable as the materials in radiation-proof construction.

\section{References}

[1] Ş. Kılınçarslan, Ph.D. Thesis, Suleyman Demirel Univ., Institute of Natural and Applied Science, 2004.

[2] I. Akkurt, C. Basyigit, S. Kilincarslan, B. Mavi, Prog. Nucl. Energy 46, 1 (2014).

[3] I. Akkurt, C. Basyigit, S. Kilincarslan, B. Mavi, A. Akkurt, Cement and Concrete Composites 28, 153 (2006).

[4] B. Jorge, N. Saikia, Recycled aggregate in concrete: use of industrial, construction and demolition waste, Springer, 2012.

[5] P. Fazile, Ş. Kilinçarslan, Acta Phys. Pol. A 125, 275 (2014).

[6] I. Akkurt, A. Elkhayat, Ann. Nucl. Energy 51, 5 (2013).

[7] I. Akkurt, S. Kilincarslan, C. Basyigit, Ann. Nucl. Energy 31577 (2004).

[8] I. Akkurt, H. Akyıldırım, B. Mavi, S. Kilincarslan, C. Basyigit, Prog. Nucl. Energy 52, 620 (2010).

[9] H. John, S.M. Seltzer, Tables of x-ray mass attenuation coefficients and mass energy-absorption coeffcients, National Institute of Standards and Technology, 1996.

[10] I. Salinas, C. Conti, R. Lopes, Appl. Radiat. Isotopes 64, 13 (2006). 